\title{
Listeria monocytogenes IN HIV-INFECTED PATIENTS IN A HOSPITAL OF NOVA IGUAÇU, RIO DE JANEIRO, BRAZIL
}

\author{
NORBERG A. N. (1), MAURE E. A. P. (2, 3), SVAITER N. (1), \\ GONÇALVES A. S. (1), SANCHES F. G. $(1,4)$
}

(1) Iguaçu University (UNIG), Rio de Janeiro, Brazil; (2) Volta Redonda Universitary Center, Rio de Janeiro, Brazil; (3) National Institute of Agricultural Research and Development (INIDA), Cape Verde; (4) Souza Marques Technical-Educational Foundation, Rio de Janeiro, Brazil

ABSTRACT: A survey was carried out in a hospital of Nova Iguaçu, Rio de Janeiro, Brazil, in the period from July 1999 to March 2002, to determine the infection rate of Listeria monocytogenes in HIV+ patients with diarrhea symptoms; 134 samples were processed by microbiological methods. The results demonstrated $12.68 \%$ of positive samples. However, no statistical differences were observed for age or sex in the studied group, suggesting that this microorganism should be regarded in the differential diagnosis of infectious processes in HIV+ patients in the area.

KEY WORDS: Listeriosis, HIV, diarrhea.

\section{CORRESPONDENCE TO:}

ANTONIO NERES NORBERG, Rua Barão de Bom Retiro, 2600, ap. 1001, 20540340, Grajaú, Rio de Janeiro, RJ, Brasil. Email: norberg@uol.com.br. 
Listeria monocytogenes is the bacterium responsible for listeriosis. This microorganism can infect several species of animals including human beings (3). According to Chagas et al. (2), the disease can cause septicemia, mononucleosis, abortion, meningitis, encephalitis, prenatal and perinatal infections, and areas of necrosis in the liver of infected species. The growing and morphology of the genus are similar to those of the diphtheria agent. These bacteria can cause beta-hemolysis in blood agar and glycosilate tryptosade agar. After the infection, the bacterium is eliminated of the organism in approximately four weeks. The microorganism can be found in the digestive tract, facilitating the transmission by asymptomatic carriers. The incidence is variable, being higher in individuals in contact with symptomatic patients. The microorganism is difficultly isolated from feces, hindering a diagnosis. According to Jurado et al. (4), this fact facilitates underestimating its incidence. Using this information as a basis and regarding the shortage of information in the area, we decided to carry out this survey.

The survey was carried out in a hospital of Nova Iguaçu, Rio de Janeiro, Brazil. The collection was performed from $134 \mathrm{HIV}+$ patients with intestinal symptoms. The samples were collected in the period from July/1999 to March/2002, using sterile swabs and transported in Stuart Agar medium. The material was plated in Listeria enriched broth and incubated at $4^{\circ} \mathrm{C}$.

The obtained growth was weekly cultured in Listeria Selective Agar Base and Blood Agar, and incubated at $37^{\circ} \mathrm{C}$ for $24 \mathrm{~h}$. The colonies were identified by morphological characteristics and mobility at $25^{\circ} \mathrm{C}$ [Gram's method with Koppelof-Beerman modification] (1). The confirmation was achieved by biochemical and serologic tests (BioMerieux Vitek; Fast agglutination test). Statistical analysis (Fisher test; $p<0.05$ ) was also carried out using a computer program (Bioestat 2.0). The result demonstrated $12.68 \%$ of positive samples, corroborating the reports of Qayyum et al. (7). However, no statistical difference related to age group and sex was observed. In this case, the infection was related with a diarrhea, highlighting thus its epidemiological interest. It is important to emphasize that the clinical manifestations are varied, meaning that several problems could be developed in infected patients (6). We must emphasize that the frequency of cases is not only related with immunosuppression and thermotolerance in low temperatures, but with the possibility of asymptomatic carriers, which could serve as new focuses of infection. This result indicates that situations related with HIV infection (epidemiology and treatment) could 
increase the possibility of Listeria infection in the community $(5,8)$. We must remind that in the community, an oral contamination (by ingestion of foods contaminated with feces or non-pasteurized milk) facilitates the occurrence of outbreaks. Currently, no vaccines exist; in the county hospitals, no routine diagnoses are performed; and it is practically impossible to avoid the contact with the microorganism in the environment, reason why we suggest it should be regarded in the differential diagnosis of infectious processes, which are developing in HIV+ patients of the county.

Table 1. Occurrence of Listeria monocytogenes in HIV-infected patients, assisted in the General Hospital of Nova Iguaçu, Rio de Janeiro, Brazil, from July/1999 to March/2002.

\begin{tabular}{c|c|c|c|c}
\hline & \multicolumn{2}{|c|}{ Examined samples } & \multicolumn{2}{c}{ Positive samples } \\
\hline $\begin{array}{c}\text { Age group } \\
\text { (years) }\end{array}$ & $\begin{array}{c}\text { Male } \\
\text { patients }\end{array}$ & $\begin{array}{c}\text { Female } \\
\text { patients }\end{array}$ & $\begin{array}{c}\text { Male } \\
\text { patients }\end{array}$ & $\begin{array}{c}\text { Female } \\
\text { patients }\end{array}$ \\
\hline \hline $15-20$ & $4(2.98 \%)$ & $0(0 \%)$ & $0(0 \%)$ & $0(0 \%)$ \\
$21-25$ & $6(4.47 \%)$ & $3(2.23 \%)$ & $2(1.49 \%)$ & $0(0 \%)$ \\
$26-30$ & $22(16.41 \%)$ & $13(9.70 \%)$ & $3(2.23 \%)$ & $1(0.74 \%)$ \\
$31-35$ & $28(20.89 \%)$ & $16(11.94 \%)$ & $4(2.98 \%)$ & $2(1.49 \%)$ \\
$36-40$ & $17(12.68 \%)$ & $14(10.44 \%)$ & $2(1.49 \%)$ & $1(0.74 \%)$ \\
$>40$ & $6(4.47 \%)$ & $5(3.73 \%)$ & $2(1.49 \%)$ & $0(0 \%)$ \\
\hline Total & $83(61.94 \%)$ & $51(38.05 \%)$ & $13(9.70 \%)$ & $4(2.98 \%)$ \\
\hline \hline
\end{tabular}

Fisher's test $(p>5 \%)$

\section{REFERENCES}

1 BIER O. Técnicas bacteriológicas. In: BIER O. Microbiologia e imunologia. 23. ed. Rio de Janeiro: Melhoramentos, 1984: 984.

2 CHAGAS JA., FIGUEIREDO LMH, FREIRE HBM. Listeriose. In: NEVES J. Diagnóstico e tratamento das doenças infectuosas e parasitárias. Rio de Janeiro: Guanabara Koogan, 1978: 409-15.

3 HUTYRA VF., MAREK J. Listeriosis. In: HUTYRA VF., MAREK J. Terapeuticas especiales de los animales domesticos. Rio de Janeiro: Labor, 1966: 67-87.

4 JURADO RL., FARLEY MM., PEREIRA E. Increased risk of meningitis and bacteremia due to Listeria monocytogenes in patients with human immunodeficiency virus infection. Clin. Infect. Dis., 1993, 17, 224-7. 
5 McLAUCHLIN J., AUDURIER A., TAYLOR AG. Treatment failure and recurrent human listeriosis. J. Antimicrob. Chemother., 1991, 27, 851-7.

6 MORGAN JH. Human infection of Listeria monocytogenes. Ugeskr. Laeger, 1977, 120, 701-7.

7 QAYYUM QJ., SCERPELLA EG., MORENO JN., FISCHL MA. Report of 24 cases of Listeria monocytogenes infection at the University of Miami Medical Center. Rev. Invest. Clin., 1997, 49, 265-70.

8 SKOGBERG K., SYSJANEN J., JAHKOLA M. Clinical preservation and outcome of listeriosis in patients with and without immunosuppressive therapy. Clin. Infect. Dis., 1992, 14, 815-21. 